\title{
Covid-19: Over 300 Italian doctors and scientists call for more testing
}

\author{
Marta Paterlini
}

Stockholm

More than 300 Italian doctors and scientists have called on the prime minister, Giuseppe Conte, and local authorities to use their skills and facilities to ramp up RNA testing to identify mild and asymptomatic cases of covid-19, which they have said account for $80 \%$ of all cases and are helping to spread the contagion.

"Given the dramatic emergency in which our country finds itself, we consider it our civic duty to intervene as scientists equipped with technical skills," they said in an open letter to the heads of national and regional government. "In many other countries (including China, France, Austria, and Germany) academic laboratories with high level skills have been co-opted in order to provide equipment and staff for the extension of diagnostic tests," they said. "In Italy there is an extraordinary community of researchers who could contribute immediately and very significantly and at zero cost to the current emergency situation."

Ruggero De Maria, professor of pathology at the Catholic University in Rome, who helped coordinate the appeal signed by 36 research institutes and another 25 biomedical bodies, said "We are very concerned about the current events." He said that wider testing of the population was vital to protect health workers and providers of essential services.

Another of the signatories, Sergio Romagnani, a professor of clinical immunology at the University of Florence, has previously reported how blanket testing in a completely isolated village of roughly 3000 people in northern Italy saw the number of people with covid-19 symptoms fall by over $90 \%$ within 10 days. ${ }^{1}$ He said that his research indicated that most people infected with the covid-19 virus showed no symptoms but were still able to infect others, which has huge implications for testing policy, particularly in hospitals.

As of Thursday 26 March, there were 80539 confirmed cases of covid-19 in Italy and 8165 deaths. The mortality rate has reinforced the belief among many scientists that a vast swathe of mildly ill or asymptomatic cases is going undetected in Italy. The 300 signatories of the open letter said that people with mild disease were still capable of spreading covid-19, hence the need for them to be identified and isolated.

Despite the almost one month long lockdown, the number of new infections in Italy grew between Wednesday and Thursday this week. Lombardy, in northern Italy, continues to see by far the most cases as well as the most deaths from the virus. Hospitals in Milan, Bergamo, and Brescia are struggling to cope. So far, just over 250000 tests for SARS-CoV-2— the cause of covid-19-have been conducted in Italy. But since 26 February most of the tests have been done on patients in hospital.

Another of the signatories calling for an extension of testing is Pier Giuseppe Pelicci, co-scientific director of the European Institute of Oncology in Milan. He said that his facility was ready and willing to help in a ramped up national testing campaign. "Our high throughput facilities, already capable of working on much more complex systems, are available to the nation to scale up to thousands of tests per day instead of dozens," he said.

The experts are proposing an increase in high throughput laboratory tests and the development of home testing kits. Being able to test people in their homes, they said, would help prepare the country for the subsequent phases of the epidemic.

"We have to manage the tail of the epidemic, thus preventing another one from starting. We must, for example, understand how immunity works, how and if it lasts over time, and we have to monitor those who have recovered," said Pelicci.

Day M. Covid-19: identifying and isolating asymptomatic people helped eliminate virus in Italian village. BMJ 2020;368:m1165. 10.1136/bmj.m1165 32205334

Published by the BMJ Publishing Group Limited. For permission to use (where not already granted under a licence) please go to http://group.bmj.com/group/rights-licensing/ permissions 